\title{
オーステナイト系 $\mathrm{Fe}-32.5 \mathrm{wt} \% \mathrm{Ni}-\mathrm{Ti}$ およ゙゙ $\mathrm{Fe}-32.5 \mathrm{wt} \% \mathrm{Ni}-\mathrm{Be}$ 合金における粒界反応
}

\author{
近 崎 充 夫* 添 野 浩*
}

Mitsuo Chigasaki and Kô Soeno : Cellular Precipitation in Fe-32.5 wt\% Ni-Ti and $\mathrm{Fe}-32.5 \mathrm{wt} \% \mathrm{Ni}-\mathrm{Be}$ Austenitic Steels. Precipitation in Fe-32.5 wt $\% \mathrm{Ni}-(2,4,5) \mathrm{wt} \% \mathrm{Ti}$ and $\mathrm{Fe}-32.5 \mathrm{wt} \% \mathrm{Ni}-(0.24,0.49,0.66) \mathrm{wt} \%$ Be austenitic steels has been investigated by microscopy and hardness measurement. Besides homogeneous precipitation, cellular precipitation is observed. Cellular precipitation leads to the formation of cells with lamellar morphology and the matrix orientation changes discontinuously across the cell boundary. It is also observed that cellular precipitation becomes remarkable with increasing $\mathrm{Ti}$ or Be content.

Effects of small amounts of additional elements on the cellular precipitation have been investigated. Cellular precipitation is markedly suppressed by small additions of $\mathrm{Nb}$ or $\mathrm{Zr}$, though higher aging temperature decreases the effect of these elements rapidly. Recrystallization of cold worked Fe-32.5 wt\% $\mathrm{Ni}$ austenitic steels containing small amounts of ternary additional elements has also been investigated. It is shown that the elements which raise the recrystallization temperature of the Fe-32.5wt\% Ni austenitic steel have a tendency to suppress the cellular precipitation in the $\mathrm{Fe}-32.5 \mathrm{wt} \% \mathrm{Ni}$ austenitic steels containing 2 to $5 \mathrm{wt} \%$ Ti or 0.24 to $0.66 \mathrm{wt} \% \mathrm{Be}$. The results are discussed from the point of view that the interaction between additional elements and grain boundary is similar to that between additional elements and cell boundary.

(Received September 30, 1975)

\section{I. 緒言}

粒界反席は絈晶粒界から登生したマトリックスと析出相 との層状組織が結晶粠内入移動することによって進行し， 多くの場合, 粒界反応界面すなわち七儿界面は大傾角粒界 とみなすことがでさる(1)〜出．したがって粒界移動といら 観点炕たてば，粒界反応を再結晶之類似の現象としてとら えることができる。，著者らは先にマルテンサイト系Fe$\mathrm{Ni}-\mathrm{Al}$ 乱よび Fe-Ni-Be 合金に和计る盖界反応の発生に ついて検討し，粒界反応の防止，抑制のためにはマルテン サイト系 $\mathrm{Fe}$ - Ni 合金の再結晶蕰度を上昇させる $\mathrm{Nb}, \mathrm{Ti}$ ， Moなとの添加が有効であることを指摘した(5).

本報告は，オーステナイト系 Fe-32.5 wt \% Ni-Ti 牛 よび $\mathrm{Fe}-32.5 \mathrm{wt} \% \mathrm{Ni}-\mathrm{Be}$ 合金に拈ける粒界反応の発生な らびに各種添加元素による粒界反応の抑制効果を，それら の添加元素がオーステナイト系Fe-32.5 wt \% Ni 合金の 再結晶に及ぼす影響と比較して検討した結果である。

\section{II. 実 験 方 法}

Table 1 亿試料の化学組成を示す。Fe-32.5 wt \% NiTi 和よび Fe-32.5 wt\% Ni-Be飞対する添加元素として は Nb, Zr, Ti, Mo, V, W , Cu, Cr，Coなどをえらんだ。 試料の溶解, 加工お゙ず実験方法などは先の報告とほぼ同 様なので詳細を省略する。ただ試料 [A]の溶体化処理

* 株式会社日立製作所日立研究所 (Hitachi Research Laboratory, Hitachi Ltd., Hitachi)
は $1150^{\circ} \mathrm{C} て ゙ 1 \mathrm{hr}$ 保持後水冷とした。 また再結晶温度測 定用の試料 [B]については $1000^{\circ} \mathrm{C}$ で $30 \mathrm{~min}$ 烓鈍し，100 ${ }^{\circ} \mathrm{C}$ で† $75 \%$ 加工して，こ社を $500^{\circ} \mathrm{C}$ から $900^{\circ} \mathrm{C}$ まの各 温度でそれぞれ $30 \mathrm{~min}$ 烧鈍した時の引張り強さの減少か ら再結晶温度を推定した。な赫試料 [A]の平均の結晶粒 径は Fe-32.5 wt \% Ni-Ti 系合金で約 $150 \mu, \mathrm{Fe}-32.5 \mathrm{wt}$ $\% \mathrm{Ni}-\mathrm{Be}$ 系合金で約 $200 \mu$ であった。

\section{III． 実験結果および検討}

\section{Fe-32.5 wt\% Ni-Be および Fe-32.5 wt\% Ni-Ti} 合金における粒界反底と均一析出

Fe-32.5 Ni-Be および Fe-32.5 Ni-Ti 合金ではマルテ ンサイト系 $\mathrm{Fe}-\mathrm{Ni}-\mathrm{A} 1, \mathrm{Fe}-\mathrm{Ni}$ - Be 合金と同様(5)(7)(8)，粒 界反応と均一析出とが並行して進行する.Photo.1に光学 顕微鏡組織を示したが，濃く腐食された部分が粒界反応部 である。結晶粒界によって，また同一の結晶粒界でる場所 によって粒界反応の発生にかなりの差が認められる。な拉 いずれの合金においても Photo.1(a)にみられるような結 晶榼内を直線状に走る焼鈍双晶がしばしば観察されたが， 粒界反応恃双晶境界からは発生しにくい上らで西る。粒界 反応は結晶粒界から成長したいくつかのセルからなってい る. 各也ルは Photo.2の透過電子顕微鏡組織に示したよ らにマトリックスと析出相との層状組織である。セル内の 析出相の層間隔は時効温度が低いほど，また溶質原子濃度

$\dagger$ Kaufman と Cohen ${ }^{(6)}$ によれば Fe-32.5 Ni 合金の $\mathrm{Md}$ 点, Ms 点はそれぞれ約 $25^{\circ} \mathrm{C},-155^{\circ} \mathrm{C}$ である。 
Table 1 Chemical compositions of the alloys used.

\begin{tabular}{|c|c|c|c|c|c|}
\hline \multicolumn{2}{|c|}{ Alloy system } & $\mathrm{Be}(\mathrm{wt} \%)$ & $\mathrm{Ti}(\mathrm{wt} \%)$ & Elements added (at $\%)$ & $\operatorname{Mn}(w t \%)$ \\
\hline \multirow[t]{2}{*}{ [A] } & $\begin{array}{l}\mathrm{Fe}-32.5 \mathrm{wt} \% \\
\mathrm{Ni}-\mathrm{Be}\end{array}$ & $\begin{array}{l}0.24 \\
0.49 \\
0.66 \\
0.66 \\
0.66 \\
0.66 \\
0.66 \\
0.66 \\
0.66 \\
0.66 \\
0.66 \\
0.66\end{array}$ & $\begin{array}{l}= \\
= \\
= \\
= \\
= \\
= \\
= \\
=\end{array}$ & $\begin{array}{c}\overline{-} \\
\overline{-} \\
\mathrm{Nb}: 0 . \overline{1} \\
\mathrm{Zr}: 0 . \overline{1} \\
\mathrm{Ti}: 0 . \overline{1}, 0.5 \\
\mathrm{Mo}: 0 . \overline{1} \\
\mathrm{~V}: 0.5 \\
\mathrm{~W}: 0.5 \\
\mathrm{Cu}: 1.0 \\
\mathrm{Cr}: 1.0 \\
\mathrm{Co}: 1.0\end{array}$ & $\begin{array}{l}0.2 \\
0.2 \\
0.2 \\
0.2 \\
0.2 \\
0.2 \\
0.2 \\
0.2 \\
0.2 \\
0.2 \\
0.2 \\
0.2\end{array}$ \\
\hline & $\begin{array}{l}\mathrm{Fe}-32.5 \mathrm{wt} \% \\
\mathrm{Ni}-\mathrm{Ti}\end{array}$ & $\begin{array}{l}- \\
= \\
= \\
= \\
= \\
= \\
= \\
=\end{array}$ & $\begin{array}{l}2 \\
4 \\
5 \\
5 \\
5 \\
5 \\
5 \\
5 \\
5 \\
5 \\
5\end{array}$ & $\begin{array}{c}- \\
\overline{-} \\
\mathrm{Nb}: 0 . \overline{1}, 0.5 \\
\mathrm{Zr}: 0.1 \\
\mathrm{Mo}: 0 . \overline{1} \\
\mathrm{~V}: 0.5 \\
\mathrm{~W}: 0.5 \\
\mathrm{Cu}: 1.0 \\
\mathrm{Cr}: 1.0 \\
\mathrm{Co}: 1.0\end{array}$ & $\begin{array}{l}0.2 \\
0.2 \\
0.2 \\
0.2 \\
0.2 \\
0.2 \\
0.2 \\
0.2 \\
0.2 \\
0.2 \\
0.2\end{array}$ \\
\hline [B] & $\begin{array}{l}\mathrm{Fe}-32.5 \mathrm{wt} \% \\
\mathrm{Ni}\end{array}$ & $\begin{array}{l}= \\
= \\
= \\
= \\
= \\
=\end{array}$ & $\begin{array}{l}= \\
= \\
= \\
= \\
= \\
=\end{array}$ & $\begin{array}{l}\text { Nb }: 0 . \overline{1}, 0.5,1.0 \\
\mathrm{Zr}: 0.1,0.5,1.0 \\
\mathrm{Ti}: 0.1,0.5 \\
\mathrm{Mo}: 0.1,3.0 \\
\mathrm{~V}: 0.5,1.0 \\
\mathrm{~W}: 1.0,3.0 \\
\mathrm{Cu}: 1.0,3.0 \\
\mathrm{Cr}: 5.0 \\
\mathrm{C} 0: 1.0,5.0\end{array}$ & $\begin{array}{l}0.1 \\
0.1 \\
0.1 \\
0.1 \\
0.1 \\
0.1 \\
0.1 \\
0.1 \\
0.1 \\
0.1\end{array}$ \\
\hline
\end{tabular}

が高い涪どせまくなる傾向であっだ ${ }^{(9)}$ (13). Photo.2(b)は Fe-32.5 Ni-5 Ti 合金に乱りるて界面の近傍を観察した 例である。セルの直前には微細な均一析出相が篗察され る。

電子線回折によれば，いずれの合金においてもセル内の マトりックス $(F C C \dagger)$ の結晶方位は隣接する結晶粒のマ トリックス結晶方位に注汸一致した。Photo.3 法Fe-32.5 $\mathrm{Ni}-0.66 \mathrm{Be}$ 合金の明視野像および腤視野像である。セル が結晶粒界から上下の結晶粒へを成長しょらとしている。 Photo.3 (b) の暗視野像 (下側の結晶粒の (111) 回折斑点に よる像)に特好る下側の期るい領域は同一の結昆方位をも

$\dagger$ Speich ${ }^{(14)}$ は Fe-30 Ni-6 Ti 合金の粒界反応に和い て, とくに㭙効温度が $700^{\circ} \mathrm{C}$ 以下の場合, 七儿内 のマトりックスは腈效温度からの冷却途中で $B C C$ にマルテンサイト変態することを指摘している。乙 かし本研究で用いた $\mathrm{Fe}-32.5 \mathrm{Ni}$ - (2〜5) Ti 合金和 よび Fe-32.5 Ni- (0.24〜0.66) Be 合金では後に示 す Fig.1 Fig.4 の時効処理後, 室温でX線回折 (CoK $\alpha$ 線を用いたディフラクトメーター法，フィ ルターは Fe)を行なったところいずれる $B C C$ 回折 線は钼察されなかった。拣た Speich はFe-30 Ni$6 \mathrm{Ti}$ 合金で，第 1 の粒界反応が発生した後に，さら 飞第2 の粒界反応が進行するのを観察している。乙 たがって Fe-32.5 Ni- $(2 \sim 5) \mathrm{Ti}$ 合金和いてい 2 種類の粒界反応が生じている可能性もあるが，Fig。 2 执よび Fig.4 の光学顕微鏡による粒界反応量の测 定ではそれらをとくに区別していない。
つが、これから知られるように最初楾状であった結晶粒 界はセルの形成，成長に之るなって曲線状に变化する。亦 なわちマトリックスの結晶方位はセル界面を境として不連 続的に変化して括り，粒界反応を析出にともなら一種の結 晶粒界移動現象と考えることができる。

次に $600 \sim 900^{\circ} \mathrm{C}$ 間の温度で $30 \mathrm{~min}$ 間の時効および等 洫時效に拈ける粒界反応量，均一析出部の硬度变化などを 測定した。粒界反芯量は溶質原子濃度が高いはど多くな る。Fig.1および Fig. 2 は $600^{\circ} \mathrm{C}$ から $900^{\circ} \mathrm{C}$ をの各温

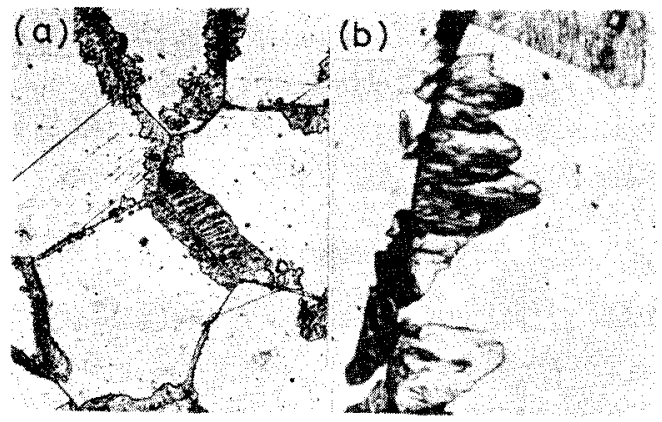

Photo. 1 Cellular precipitation in Fe-32.5 Ni-Be and $\mathrm{Fe}-32.5 \mathrm{Ni}-\mathrm{Ti}$ alloys.

(a) $\mathrm{Fe}-32.5 \mathrm{Ni}-0.49 \mathrm{Be}$ alloy aged at $550^{\circ} \mathrm{C}$ for $22 \mathrm{hr}(\times 100 \times 5 \%)$

(b) $\mathrm{Fe}-32.5 \mathrm{Ni}-5 \mathrm{Ti}$ alloy aged at $750^{\circ} \mathrm{C}$ for $0.5 \mathrm{hr}(\times 800 \times 5 \%)$ 
度で $30 \mathrm{~min}$ 㭙效した結果である。粒界居応量新よび均一 析出による硬度変化はいず机子上に凸の結果を示すが，そ

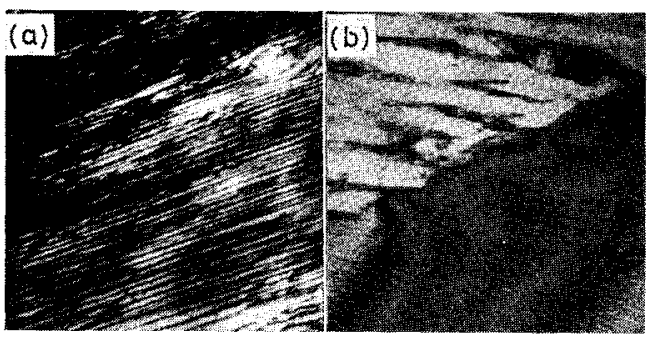

Photo.2 Thin foil electron microscopy of cellular precipitation.

(a) Fe-32.5 Ni-0.66 Be alloy aged at $550^{\circ} \mathrm{C}$ for $5 \mathrm{hr}(\times 26000 \times 2 / 3)$

(b) $\mathrm{Fe}-32.5 \mathrm{Ni}-5 \mathrm{Ti}$ alloy aged at $750^{\circ} \mathrm{C}$ for $0.5 \mathrm{hr}(\times 40000 \times 2 / 3)$

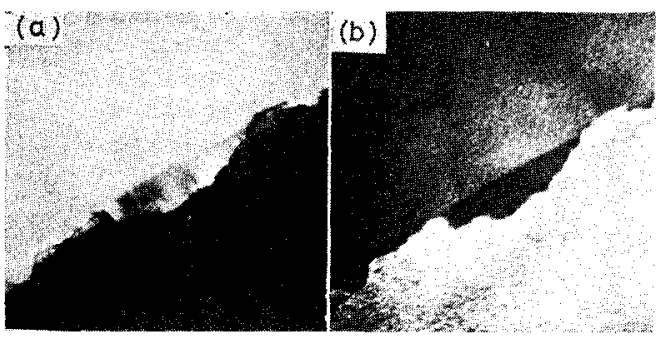

Photo.3 Thin foil electron microscopy of cellular precipitation in Fe-32.5 $\mathrm{Ni}-0.66 \mathrm{Be}$ alloy aged at $550^{\circ} \mathrm{C}$ for $1.5 \mathrm{hr} .(\times 26000 \times 2 / 3)$

(a) A bright field image

(b) A dark field image formed by (111) diffracted beam of the lower grain

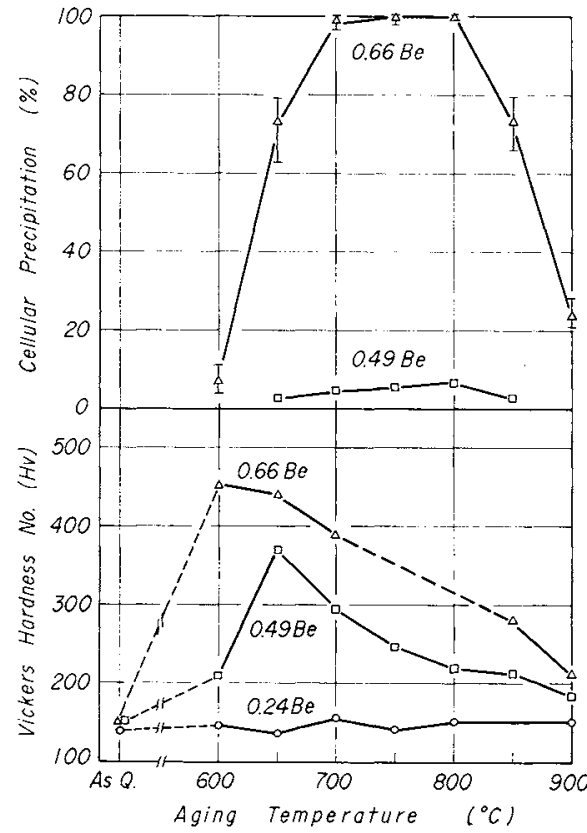

Fig.1 Effect of aging temperature on cellular precipitation and hardness in homogeneously precipitated regions for the $\mathrm{Fe}$ $32.5 \mathrm{Ni}$-Be alloys. Aging time $: 30 \mathrm{~min}$.
れらのピークに対応する温度は粒界反応量の方が高温とな る。むた粒界反底量に着目すれば，溶質原子濃度が高いは ど粒界反応㱸のピーク洫度は高温側にずれる傾向である。

䊉界度応量は倍率 100 倍の光学湿徽鏡の視野から点算法 で約 10 倠の試料について测等してその平均値をとった が(5)，硬度の測企值に比較してばらつきが大きかった。こ れは一つには結晶粒界によって粒界反応の発生に差がある ためで，組織観察の倍率を下げるかあるいは溶体化処理湿 度を下げて絬楽粒径を小さくするなとによって測定值のば らつきは少なくなると考它られる。参考のためにFig.1， Fig. 2 のe-32.5 Ni-0.66 Be, Fe-32.5 Ni-5 Ti 合金につ いて，粒界反応量のばらつきの程度を示した。

Fig.3, Fig.4 は $550^{\circ} \mathrm{C}(\mathrm{Fe}-32.5 \mathrm{Ni}-\mathrm{Be})$ 扎よび $650^{\circ} \mathrm{C}$ (Fe-32.5 Ni-Ti) 等温時効の結果である，粒界反応は溶質 原子濃度が高いほど，より短㭙閏がらしかも急速に発生す る。たと光ば Fe-32.5 Ni-0.49 Be 合金では场一析出部の 硬捜が最高値安越えて軟化しはじめた後に試料のほほ全面

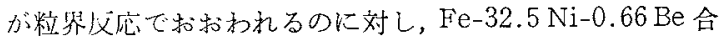
金では垃一析出部の硬度が最高值に到達する以前に粒界反

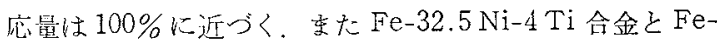
$32.5 \mathrm{Ni}-5 \mathrm{Ti}$ 合金とを此較すると，场一析出による硬化量 にはたかたか 10 数\%の差しかないが，粒界反度量は Fe$32.5 \mathrm{Ni}-5 \mathrm{Ti}$ 合金が約 3 倍程度多い。な叔 Fe-32.5 Ni-

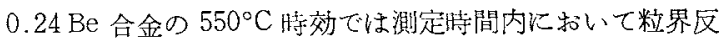
応は発生せず，硬度も汪とんど增加していない，しかし時 效温度が $650^{\circ} \mathrm{C}$ になとFig.3に破線で示したよらに， 粒界区応の発生执よび硬度の增加がわずかにみられる。

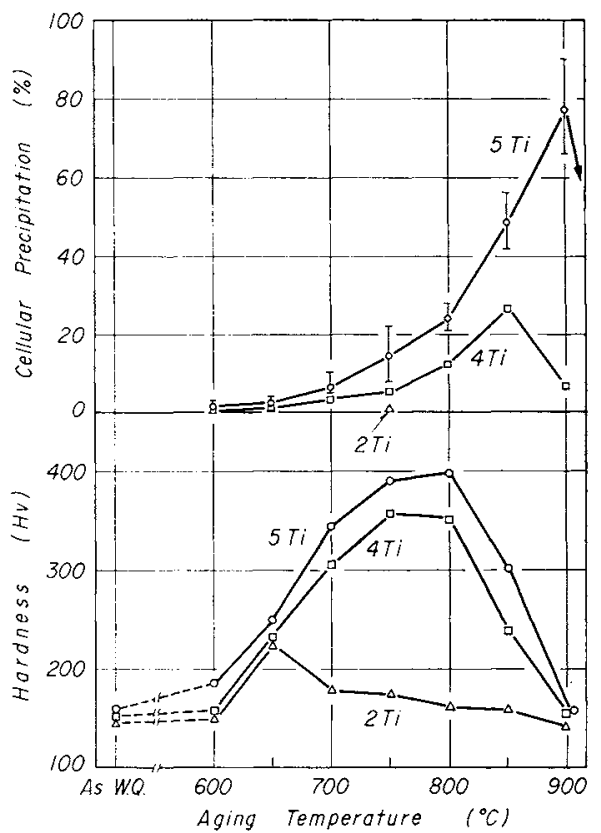

Fig.2 Effect of aging temperature on cellular precipitation and hardness in homogeneously precipitated regions for the $\mathrm{Fe}-$ $32.5 \mathrm{Ni}-\mathrm{Ti}$ alloys. Aging time : $30 \mathrm{~min}$. 
Fig.3，Fig.4には粒界反応部の硬度も示した．粒界反応部

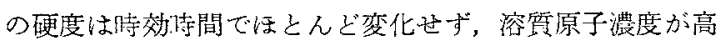

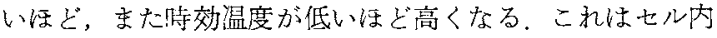
の層状析出物の層間滆の变化と対応している。すなる年層 間隔がせいい汪ど硬度は高い。

以上のベたオーステナイト系 $\mathrm{Fe}-32.5 \mathrm{Ni}-\mathrm{Be}, \mathrm{Fe}-32.5$ $\mathrm{Ni}$-Ti 合金和计る粒界反空之均一析出についての結果 は，全般的にはマルテンサイト系 $\mathrm{Fe}-\mathrm{Ni}-\mathrm{Al}, \mathrm{Fe}-\mathrm{Ni}-\mathrm{Be}$ 合金でみられたと汪ぼ同样の傾向である(5)，ただし粒界反 応あるい情一析出が影著に進行する温度はマルテンサイ 卜系合金比較してオーステナイト系合金の方がかなり高 温となる。またマルテンサイト系 $\mathrm{Fe}-\mathrm{Ni}-\mathrm{Al}, \mathrm{Fe}-\mathrm{Ni}-\mathrm{Be}$ 合金では溶質原子濃度が低くなると粒界反応嶝生せず均 一析出のみがみられたが，本研究に拈けるFe-32.5 Ni-

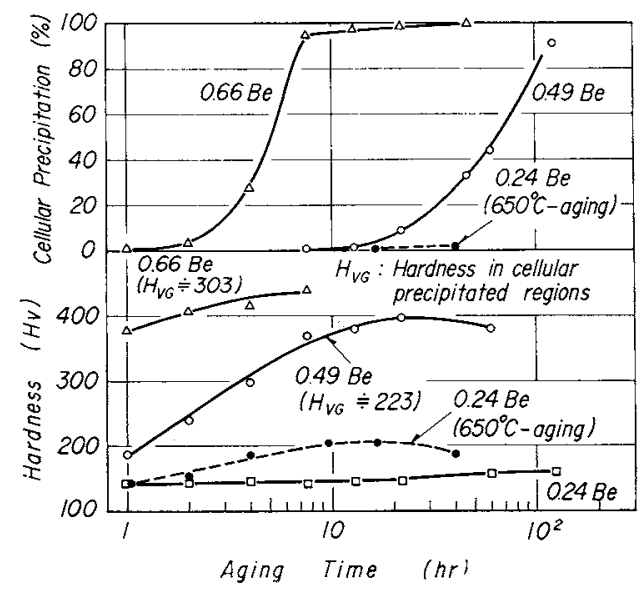

Fig.3 Amount of cellular precipitation and hardness in homogeneously precipitated regions as a function of aging time at $550^{\circ} \mathrm{C}$ for the $\mathrm{Fe}-32.5 \mathrm{Ni}-\mathrm{Be}$ alloys

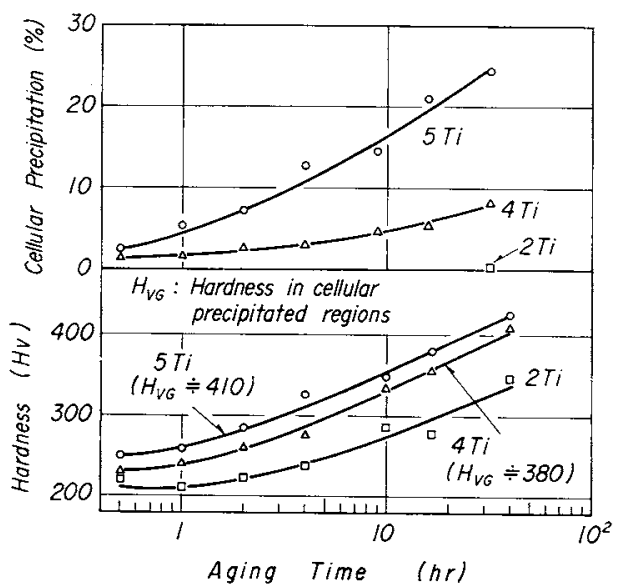

Fig.4 Amount of cellular precipitation and hardness in homogeneously precipitated regions as a function of aging time at $650^{\circ} \mathrm{C}$ for the $\mathrm{Fe}-32.5 \mathrm{Ni}-\mathrm{Ti}$ alloys.
(0.24〜0.66) Be, Fe-32.5 Ni- (2〜5) Ti 合金ではいずれる 均一析出と粒界反応とが並行して進行した。

\section{2. 粒界反応におよばす添加元素の影響}

Fe-32.5 Ni-Be，Fe-32.5 Ni-Ti 合金における粒界没応 括よび Fe-32.5 Ni 合金の再結晶におよぼす添加元素( Nb， $\mathrm{Zr}, \mathrm{Ti}, \mathrm{Mo}, \mathrm{V}, \mathrm{W}, \mathrm{Cu}, \mathrm{Cr}, \mathrm{Co}$ ) 影響を検討した。

Fig.5, Fig.6に 75\%線引加工したFe-32.5 Ni 合金の 焼鈍による軟化におよ接す Nb, Ti， V , W 添加の影響を示 す。加工したオーステナイト系 $\mathrm{Fe}-\mathrm{Ni}$ 合金ではいずれも

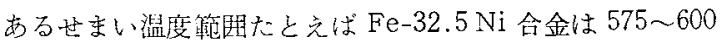
${ }^{\circ} \mathrm{C}, \mathrm{Fe}-32.5 \mathrm{Ni}-0.1$ at $\% \mathrm{Nb}$ 合金は $675 \sim 700^{\circ} \mathrm{C}$ の範囲で 抗張力が大きく減少する。.Photo.4はFe-32.5 Ni 命金の 軟化過程に括ける透過電子顏微鏡組織の変化である。再結

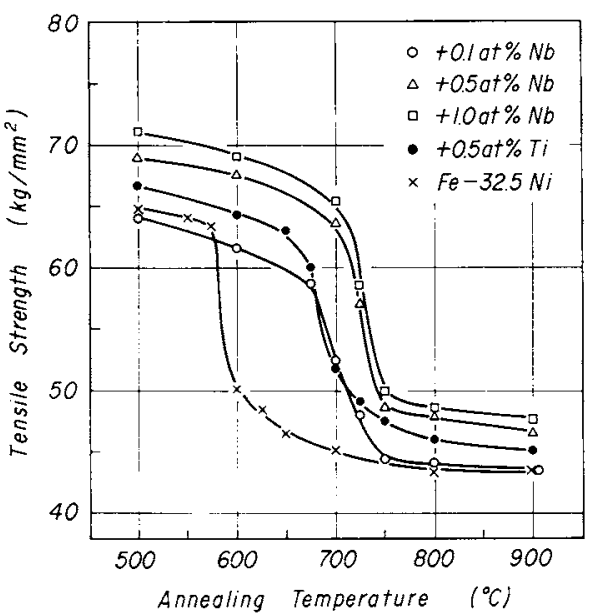

Fig.5 Annealing curves of the $75 \%$ cold drawn Fe-32.5 Ni binary alloy and the $75 \%$ cold drawn Fe-32.5 Ni ternary alloys containing $\mathrm{Nb}$ or $\mathrm{Ti}$. Annealing time $: 30 \mathrm{~min}$.

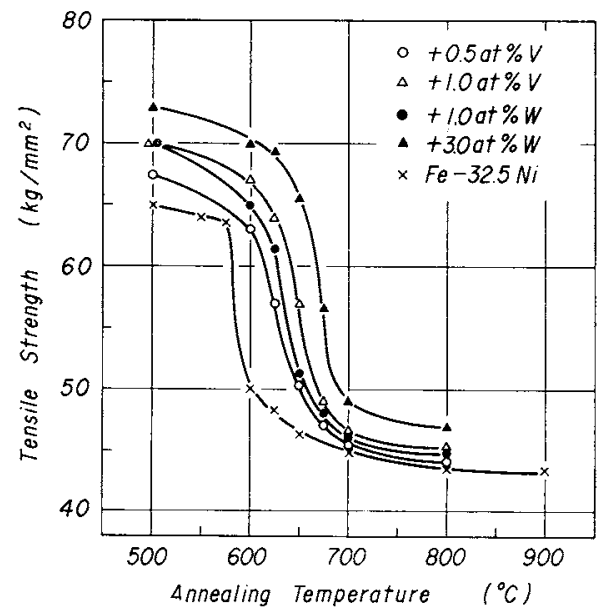

Fig. 6 Annealing curves of the $75 \%$ cold drawn Fe-32.5 Ni binary alloy and the $75 \%$ cold drawn $\mathrm{Fe}-32.5 \mathrm{Ni}$ ternary alloys containing $\mathrm{V}$ or $\mathrm{W}$. Annealing time $: 30 \mathrm{~min}$. 


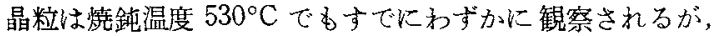

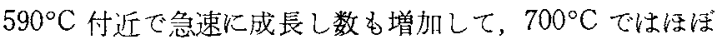
全視野が再結晶粒となる。すなわら抗張力が大さく減少す る温度範囲で再結晶が顕著に進行するのが認められた。 そ
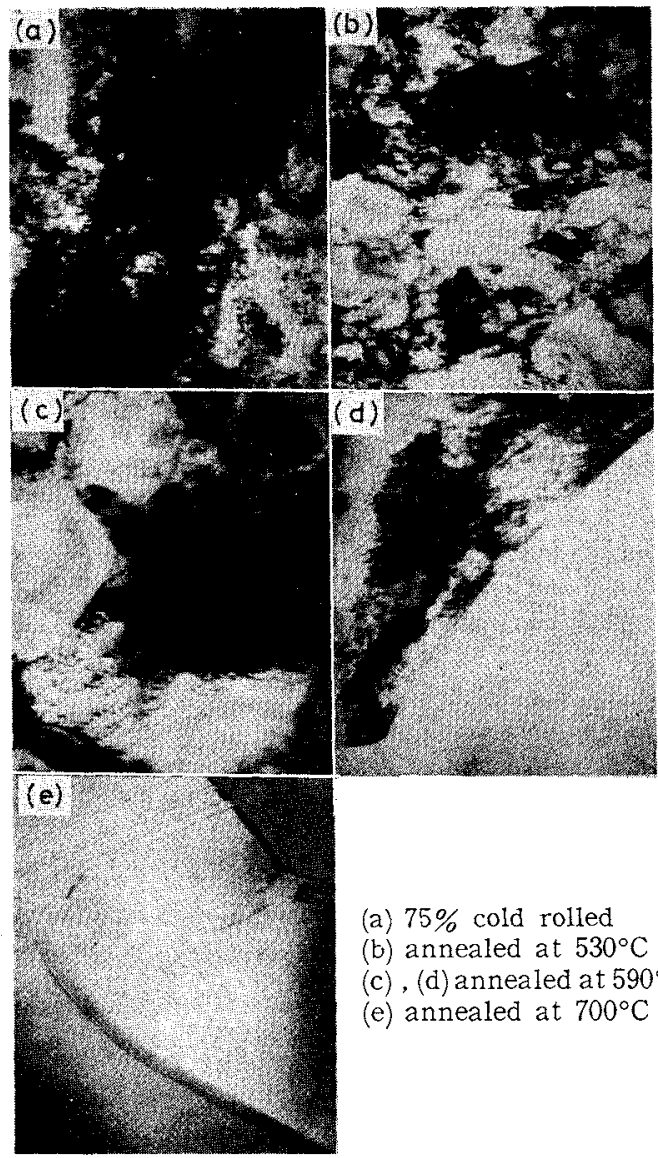

(a) $75 \%$ cold rolled

(b) annealed at $530^{\circ} \mathrm{C}$

(c), (d) annealed at $590^{\circ} \mathrm{C}$

(e) annealed at $700^{\circ} \mathrm{C}$

Photo.4 Thin foil electron microscopy of the $75 \%$ cold rolled $\mathrm{Fe}-32.5 \mathrm{Ni}$ alloy af ter annealing. Annealting time : $30 \mathrm{~min}$.

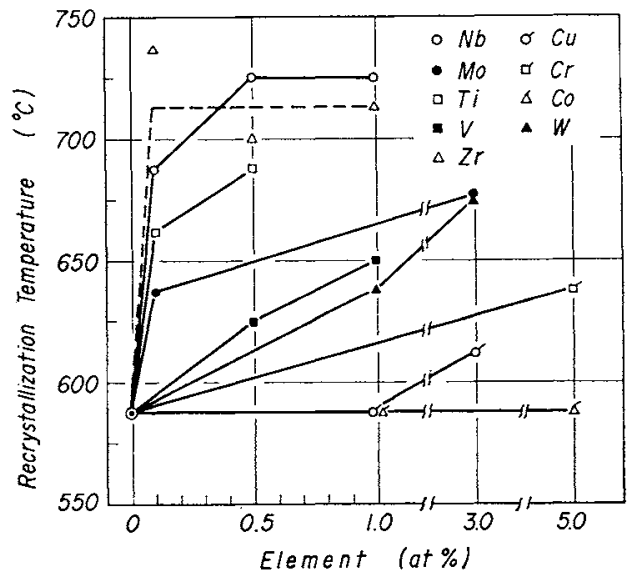

Fig.7 Effect of the elements added on the recrystallization temperature of Fe$32.5 \mathrm{Ni}$ alloy.
こで Fe-32.5 Ni 合金の再絽晶温度として便宜上抗張力が 大きく減少する $575^{\circ} \mathrm{C}$ と $600^{\circ} \mathrm{C}$ の中間の温度，一なわち $588^{\circ} \mathrm{C}$ を取った。なおこの温度はマルテンサイト系 Fe-10 at\% Ni 合金に比較して約 $120^{\circ} \mathrm{C}$ 高い(5).Fig.7は以上の よらにして求めた再結晶温度を各添加元素についてまとめ た結果である， $\mathrm{Fe}-32.5 \mathrm{Ni}$ 合金の再結晶温度は， $\mathrm{Nb}, \mathrm{Zr}$ ， $\mathrm{Ti}$ ，Moなどの添加によって顕著に上昇する。

Fig.8 は Fe-32.5 Ni-0.66 Be 合金を各温度で $30 \mathrm{~min}$ 時效した後の粒界反応量に和よばす添加元素の影響であ

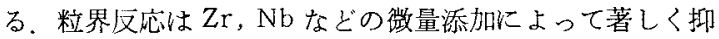
制されるが，Cu，Co，Crなとはわずかな抑制効果を示すの みである。この結果を $\mathrm{Fe}-32.5 \mathrm{Ni}$ 合金の再結晶温度に就 よばす添加元素の影響(Fig.7) と比較すると, Fig.8から， 精軎仅应を抑制する效果は $\mathrm{Zr}, \mathrm{Nb}, \mathrm{Ti}, \mathrm{Mo}, \mathrm{V}, \mathrm{W}, \mathrm{Cr}, \mathrm{Cu}$, Coの順序で低減するとみられ，粒界反応の抑制和よび再 結晶温度の上犁に拈よ注す添加元素の影響は類似の傾向を 示している。な打 Ti 添加の場合にみられるように添加量 が多い在ど粒界反応を抑制する效果が大さくなる，Fig.9 は Fe-32.5 Ni-0.66 Be 合金の $550^{\circ} \mathrm{C}$ 等温時効に和ける粒 界反応量に扎よぼす添加元素の影響である、 $\mathrm{Zr}, \mathrm{Nb}$ など は結晶粒界にお汁るセルの形成を遅らせると同時にセルの 移動速度を低下させることによって粒界反心の発生量を顕 著に抑制している。これらの效果は先の報告で指摘したよ らに Fe-32.5 Ni 合金の再結晶温度を上昇させる微量の

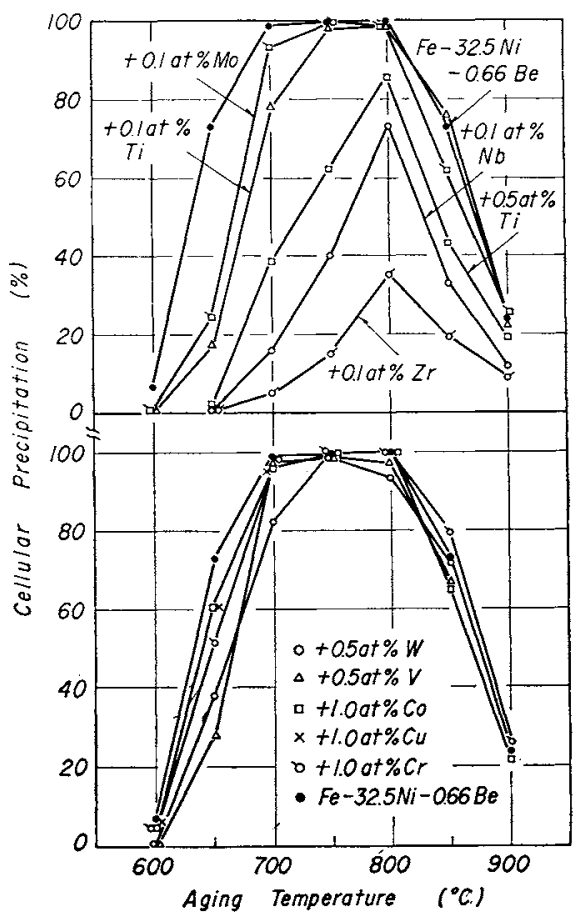

Fig.8 Effect of the elements added on the amount of cellular precipitation in the Fe-32.5 Ni-0.66 Be alloy. Aging time: $30 \mathrm{~min}$. 
Zr，Nbなどが Fe-32.5 Ni-PE合金の結晶粒界あるいは移 動するセル界面に優先的に扁析することによると考えられ $ろ^{(3)(15) \sim(20)}$.ただし粘界反応と並行して結晶䊀内では均 一析出子進斦している。したがって粒界上でのセルの形成 が遲れた場合，均一析出の進行によるセル界面前方での析 出の駆動力の低下は一層大きくなりこの効果もセル界面 の移動速度の低下に寄与していると考光られる(21)(22).

Fig. 10，Fig.11 は Fe-32.5 Ni-5 Ti 合金の等時時效㧈 よび $650^{\circ} \mathrm{C}$ 等温時効に対する添加元素の影響である. Fe$32.5 \mathrm{Ni}-5$ Ti 合金に扣ける粒界反応の钟制には Nb が最も

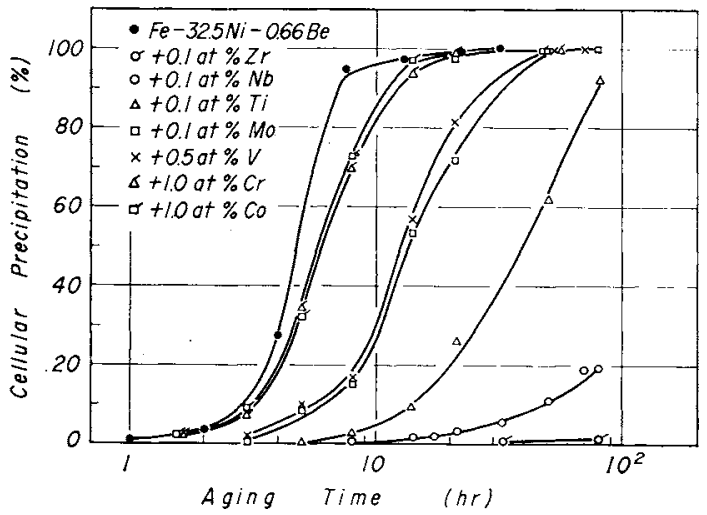

Fig.9 Effect of $\mathrm{Zr}, \mathrm{Nb}, \mathrm{Ti}, \mathrm{Mo}, \mathrm{Cr}$ or $\mathrm{Co}$ addition on the amount of cellular precipitation in the $\mathrm{Fe}-32.5 \mathrm{Ni}-0.66 \mathrm{Be}$ alloy aged at $550^{\circ} \mathrm{C}$

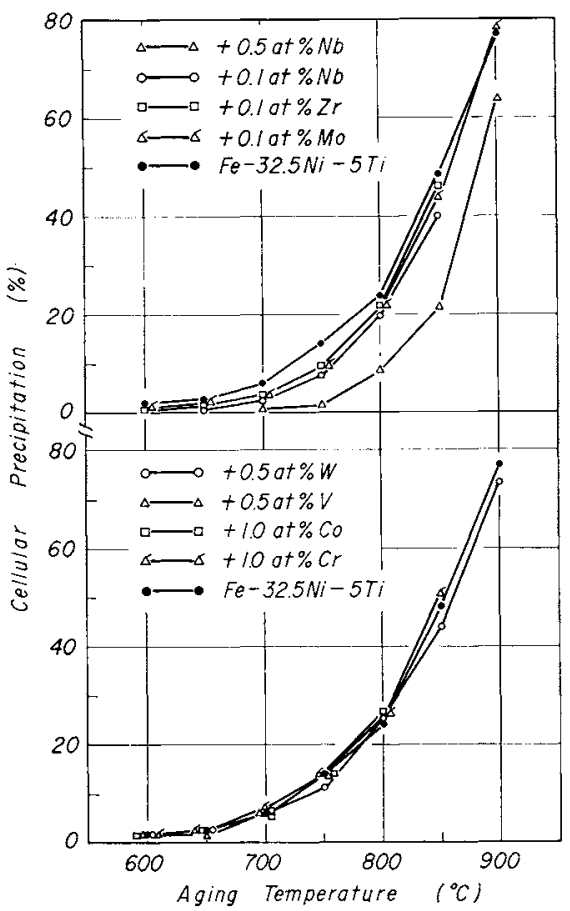

Fig.10 Effect of the elements added on the amount of cellular precipitation in the Fe-32.5 Ni-5 Ti alloy. Aging time: $30 \mathrm{~min}$.
有効で次いでZrが続さ，Moもわずかに抑制効果を示す. 一方 $\mathrm{Cu}, \mathrm{C} 0$ はやはり粒界反灾を抑制しないが，Ti 比較 して再繥晶温度上昇の効果がかなり小さい $\mathrm{V}, \mathrm{W}$ も，Fig. 10にみら机るよらにほとんど抑制効果を示さないのが注目 さ机る。すなわち Fe-32.5 Ni-Ti 合金には再結晶温度を 上昇させるTi が硬化元素として含有されているので，Fe$32.5 \mathrm{Ni}-\mathrm{Ti}$ 合金に和讨る粒界反応は Ti 以上に再結晶盖 度を上昇させる $\mathrm{Nb}$ などによってはじめて有效に抑制され ると考克られる。

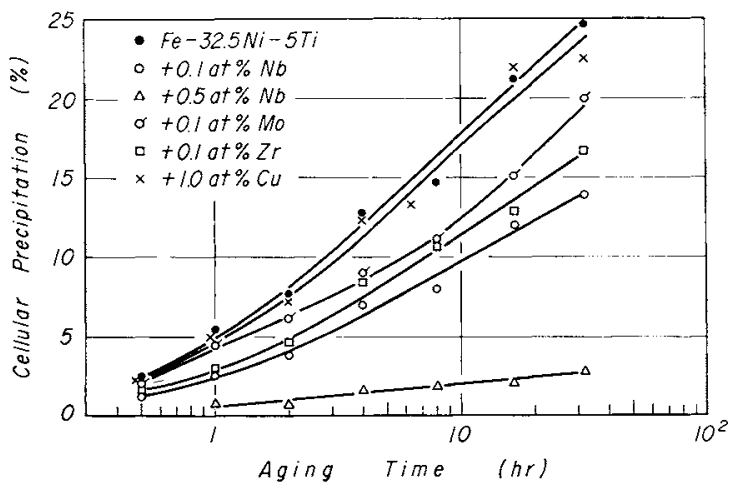

Fig.11 Effect of $\mathrm{Nb}, \mathrm{Zr}$, Mo or $\mathrm{Cu}$ addition on the amount of cellular precipitation in the $\mathrm{Fe}-32.5 \mathrm{Ni}-5 \mathrm{Ti}$ alloy aged at $650^{\circ} \mathrm{C}$.

以上のように，粒界反応と再結晶温度に拉よぼす添加元 素の影敀との間には著しい類似性がある。ただ Fe-32.5 $\mathrm{Ni}-\mathrm{Be}$ 和よび Fe-32.5 Ni-Ti 合金の粒界反応に対する $\mathrm{Nb}$ とZr の効果は逆転している。これは各種の微量添加元素 が結晶粒界あるいはセル界面に偏析する程度は Fe-32.5 $\mathrm{Ni}-\mathrm{Be}$ 合金と Fe-32.5 Ni-Ti 合金とで浪济類似してはい るが，必ずしも同一でないことを示するのと思わ礼る。そ

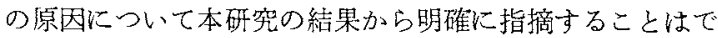
きないが，両合金に打る硬化元素，析出相の差などが偏 析状態に影響を扣よ注していると考兄られる。たとえば添 加元素がセル内の層状析出相に固浴しやすい場合には，七 儿界面で添加元素は層状析出相に吸収され，界面での添加 元素の偏析量は低下し，それにともなって界面の移動に対 する卯制力も低下するであるう。

ま大微量添加元素儿上る粒界反応の抑制効果は時效温度 の上昇とともに急速に低下する傾向で西る。Table 2 は

Table 2 Effect of $\mathrm{Zr}, \mathrm{Nb}$ or $\mathrm{Ti}$ addition on the amount of cellular precipitation in the Fe-32.5 Ni-0.66 Be alloy.

\begin{tabular}{|c|c|c|c|}
\hline Alloy & $\begin{array}{l}550^{\circ} \mathrm{C} \\
6 \mathrm{hr}\end{array}$ & $\begin{array}{l}650^{\circ} \mathrm{C} \\
30 \mathrm{~min}\end{array}$ & $\begin{array}{l}850^{\circ} \mathrm{C}, \\
30 \mathrm{~min}\end{array}$ \\
\hline $\mathrm{Fe}-32.5 \mathrm{Ni}-0.66 \mathrm{Be}$ & $75 \%$ & $73 \%$ & $73 \%$ \\
\hline $\begin{array}{l}\mathrm{Fe} 32.5 \mathrm{Ni}-0.66 \mathrm{Be}+0.1 \\
\text { at } \% \mathrm{Zr}\end{array}$ & $0 \%$ & $0.5 \%$ & $19.5 \%$ \\
\hline $\begin{array}{l}\mathrm{Fe}-32.5 \mathrm{Ni}-0.66 \mathrm{Be}+0.1 \\
\text { at } \% \mathrm{Nb}\end{array}$ & $0 \%$ & $1 \%$ & $33 \%$ \\
\hline $\begin{array}{l}\mathrm{Fe}-32.5 \mathrm{Ni}-0.66 \mathrm{Be}+0.1 \\
\text { at } \% \mathrm{Ti}\end{array}$ & $1 \%$ & $17.5 \%$ & $75.5 \%$ \\
\hline
\end{tabular}


Fe-32.5 Ni-0.66 Be 合金の粒界反応量に対する $\mathrm{Zr}, \mathrm{Nb}$, $\mathrm{Ti}$ 添加の效果を $550^{\circ} \mathrm{C}, 6 \mathrm{hr} ; 650^{\circ} \mathrm{C}, 30 \mathrm{~min}$ および 850 ${ }^{\circ} \mathrm{C}, 30 \mathrm{~min}$ 膅效について Fig.8,Fig.9 から求めて比較し たすのである。Fe-32.5 Ni-0.66 Be 合金の粒界度応量は いずれの時效条件でる73〜75\%でほぼ一定であるが，た とえば 0.1 at\% の Nbを添加した場合， $550^{\circ} \mathrm{C} ， 6 \mathrm{hr}$ 時効 後の粒界反応量か $0 \%, 650^{\circ} \mathrm{C}, 30 \mathrm{~min}$ が $1 \%$ であるのに 対して $850^{\circ} \mathrm{C}, 30 \mathrm{~min}$ では $33 \%$ と总脨に增加する。この ような時効温度の上昇にともなら抑制効果の低下は再結晶 に対する添加元素の效果を考光れば容易に推論される。す なわら $\mathrm{Nb} ＼textrm{Z r}$ などの元素は再結晶を倍止させるのでな く，単に再結晶を崌らすにすぎない，温度が高くなれば粒 界移動に対する添加元素の抑制力は熱エネルギーによって 打ら破られ，再結晶したがって糔界反応子活発に進行し得 ๖.

\section{IV. 結言}

以上の結果を要約すると次のとおりである。

(1) オ一大テナイト系Fe-32.5 Ni- (0.24〜0.66) Be 打 よび Fe-32.5 Ni-(2〜5) Ti 合金では场一析出と粒兴反応 が並行して進行するが，粒筷反応の発生は溶質原子浱度の 高い注ど顕著となる。な和いず狆の合金においてもセル内

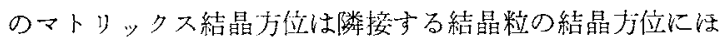
ぼ一致し，粒界反応を析Hにともなら一種の結晶粒界移動 現象としてとら光ることができる。

(2) オーステナイト系Fe-32.5 Ni 合金の再結晶盖度は $\mathrm{Nb}, \mathrm{Zr}, \mathrm{Ti}, \mathrm{Mo}$ なら添加によって著しく上昇する.

(3) Fe-32.5 Ni-Be, Fe-32.5 Ni-Ti 合金の粒界反応拉 よび Fe-32.5 Ni 合金の再結唱温度の上帠に対する微量源 加元素の影響は類似しており，粒界反応の防止，抑制には 再結晶温度を上昇させる $\mathrm{Nb} ＼textrm{Z r}$ などの添加がとくに有効 である。また添加元素による粒界反応の抑微効果は時効温

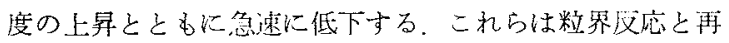

結晶を，粒界移動といら観点から，類似の現象としてとら えることができることを示している。

本研究を行ならに当り，一部測定を手伝っていただいた 比和夫氏に梓意を表する。

\section{文献}

（1）袊辺亮治: : 金属学会会報，6(1967)，435.

(2) 浚辺亮治: 合金の析出，丸善，(1972)，223.

(3) E.Hornbogen : Met.Trans., 3 (1972) , 2717.

(4) K.N.Tu : Met.Trans., 3(1972), 2769.

（5）沂崎充夫，添野 浩：金属学会誌，39(1975)，817.

(6) L.Kaufman and M.Cohen : Trans. Met.Soc. AIME, $206(1956), 1393$.

（7）金星正雄，荒木 透，涩田英夫，青木孝夫：鉄と鋼， $54(1968), 967$.

（8）金尾正雄，荒木 透，梁田英夫，中野恵司：鉄之鋼， $55(1969), 48 ; 56(1970), 1854$.

(9) J.W.Cahn : Acta Met., 7(1959), 18.

(10) D.Turnbul1 : Acta Met., 3(1955), 55.

(11) D. Turnbull : Defects in Crystalline Solids, Phys.Soc.London, (1955), 203.

(12) D. Turnbull : Impurities and Imperfection, ASM, (1955) , 121.

(13) C.Zener : Trans. Met. Soc. AIME, $167(1946)$, 550 .

(14) G.R.Speich : Trans.Met.Soc.AIME, 227 (1963), 754.

(15) K.Mäder and E. Hornbogen : Z. Metallk,, 60 (1969), 475.

(16) K.Lücke and K.Detert : Acta Met., 5(1957), 628.

(17) J.C.M.Li : J.Appl.Phys., 32(1961), 525.

(18) J.W.Cahn : Acta Met., 10 (1962), 789.

(19) K.T.Aust and J.W. Rutter : Recovery and Recrystallization, Interscience, (1963), 131.

(20) P.Gordon and R.A.Vandermeer : Recrystallization, Grain Growth and Textures, ASM, (1965), 205.

(21) H.I.Arronson and J.B.Clark : Acta Met., 16 (1968), 845.

(22) J.Petermann and E.Hornbogen : Z.Metallk., 59 (1968), 814. 